\title{
CRMP5 (Collapsin Response Mediator Protein 5) Regulates Dendritic Development and Synaptic Plasticity in the Cerebellar Purkinje Cells
}

\author{
Naoya Yamashita, ${ }^{1}$ Bedrich Mosinger, ${ }^{2}$ Arpita Roy, ${ }^{2}$ Mari Miyazaki, ${ }^{1}$ Kozue Ugajin, ${ }^{1}$ Fumio Nakamura, ${ }^{1}$ Yukio Sasaki, ${ }^{1}$ \\ Kazuhiko Yamaguchi, ${ }^{3,4}$ Pappachan Kolattukudy, ${ }^{2}$ and Yoshio Goshima ${ }^{1}$ \\ ${ }^{1}$ Department of Molecular Pharmacology and Neurobiology, Yokohama City University Graduate School of Medicine, Yokohama 236-0004, Japan, ${ }^{2}$ Burnett \\ School of Biomedical Sciences, College of Medicine, University of Central Florida, Orlando, Florida 32816, ${ }^{3}$ Laboratory for Memory and Learning, \\ ${ }^{4}$ Laboratory for Motor Learning Control, Brain Science Institute, RIKEN, 2-1 Hirosawa, Wako, Saitama 351-0198, Japan
}

Collapsin response mediator protein 5 (CRMP5) is one of the CRMP members that expresses abundantly in the developing brain. To examine the in vivo function of CRMP5, we generated $\mathrm{crmp} 5$-deficient $\left(\mathrm{crmp} 5^{-1-}\right)$ mice. Anti-calbindin immunofluorescence studies of crmp $5^{-1-}$ mice revealed aberrant dendrite morphology; specifically, a decrease in the size of soma and diameter of primary dendrite of the cerebellar Purkinje cells at postnatal day 21 (P21) and P28, but not at P14. Coincidentally, CRMP5 is detected in Purkinje cells at P21 and P28 from $c r m p 5^{+/-}$mice. In cerebellar slices of $c r m p 5^{-1-}$ mice, the induction of long-term depression of excitatory synaptic transmission between parallel fibers and Purkinje cells was deficient. Given that brain-derived neurotrophic factor (BDNF) plays major roles in dendritic development, we tried to elucidate the possible roles of CRMP5 in BDNF signaling. The effect of BDNF to induce dendritic branching was markedly attenuated in cultured $\mathrm{crmp} 5^{-1-}$ neurons. Furthermore, CRMP5 was tyrosine phosphorylated when coexpressed with neurotrophic tyrosine kinase receptor type 2 (TrkB), a receptor for BDNF, in HEK293T cells. These findings suggest that CRMP5 is involved in the development, maintenance and synaptic plasticity of Purkinje cells.

\section{Introduction}

The exquisite formation of the nervous system relies on the proper arrangement of many morphologically diverse neurons in several discrete steps. Newborn neurons must migrate to proper locations, then extend axons and dendrites into proper target regions, and form synapses with appropriate partners. These seemingly different processes all depend on the regulation of the cytoskeleton in response to extra- or intracellular cues that orchestrate the morphological development of neurons (Luo, 2000).

Collapsin response mediator protein (CRMP) was originally identified as a signaling molecule of Semaphorin3A (Sema3A) (Goshima et al., 1995). CRMPs are now known to be consisted of five homologous cytosolic proteins CRMP1-5, all of the family proteins are phosphorylated and are highly expressed in developing and adult nervous system (Minturn et al., 1995; Byk et al., 1996; Hamajima et al., 1996; Wang and Strittmatter, 1996;

Received 0ct. 8, 2010; revised Nov. 16, 2010; accepted Dec. 1, 2010.

This work was supported by Grants-in-aid for Scientific Research in a Priority Area from the Ministry of Education, Science, Sports and Culture (Y.G.), Japan Society for the Promotion of Science Research Fellowships for Young Scientists (N.Y.), and the Yokohama Medical Foundation (N.Y., Y.G.). We thank Dr. Y. Uchida and S. Chen for critical reading of our manuscript. We greatly appreciate N. Fukuda and A. Takahashi for the technical assistance.

Correspondence should be addressed to either of the following: Yoshio Goshima, Department of Molecular Pharmacology and Neurobiology, Yokohama City University Graduate School of Medicine, Yokohama 236-0004, Japan, E-mail: goshima@med.yokohama-cu.ac.jp; or Pappachan Kolattukudy, Burnett School of Biomedical Sciences, College of Medicine, University of Central Florida, Orlando, FL 32816, E-mail: pk@mail.ucf.edu.

DOI:10.1523/JNEUROSCI.5337-10.2011

Copyright $\odot 2011$ the authors $\quad 0270-6474 / 11 / 311773-07 \$ 15.00 / 0$
Fukada et al., 2000; Inatome et al., 2000; Yuasa-Kawada et al., 2003). Unphosphorylated CRMPs bind with tubulin heterodimer, whereas phosphorylation of CRMPs by Rho/ROCK kinase, cyclin-dependent kinase-5 (Cdk5) and glycogen synthase kinase- $3 \beta$ (GSK-3 $\beta$ ) lowers the binding affinity of CRMPs to tubulin (Fukata et al., 2002; Uchida et al., 2005). Recently, several knock-out mice studies demonstrated that the loss of CRMPs causes impaired cell migration, dendritic patterning and spine development (Charrier et al., 2006; Yamashita et al., 2006; Su et al., 2007; Yamashita et al., 2007; Quach et al., 2008), suggesting that CRMPs play an important role in the development of nervous system in vivo.

CRMP5 has been isolated as a CRMP-associated protein, designated CRAM (Inatome et al., 2000). CRMP5 plays an important role in regulating filopodia and growth cone morphology in neurons (Hotta et al., 2005). Like other types of CRMP family proteins, CRMP5 is expressed throughout the nervous system (Wang and Strittmatter, 1996; Fukada et al., 2000). Interestingly, anti-CRMP5 antibody is often detected in serum of patients with subacute cerebellar ataxia, and has been recognized as one of the main antibodies associated with paraneoplastic syndromes (Yu et al., 2001; Cross et al., 2003; Pittock et al., 2004; Honnorat and Antoine, 2007). However, the in vivo roles of CRMP5 remain unknown. To address this issue, we first generated crmp5deficient $\left(\mathrm{crmp} 5^{-1-)}\right.$ mice, and performed phenotypic analysis of the mutant mice. We found that dendritic development of Purkinje cells is disturbed during the period of dendritic branching, and the induction of long-term depression (LTD) of excitatory 
A
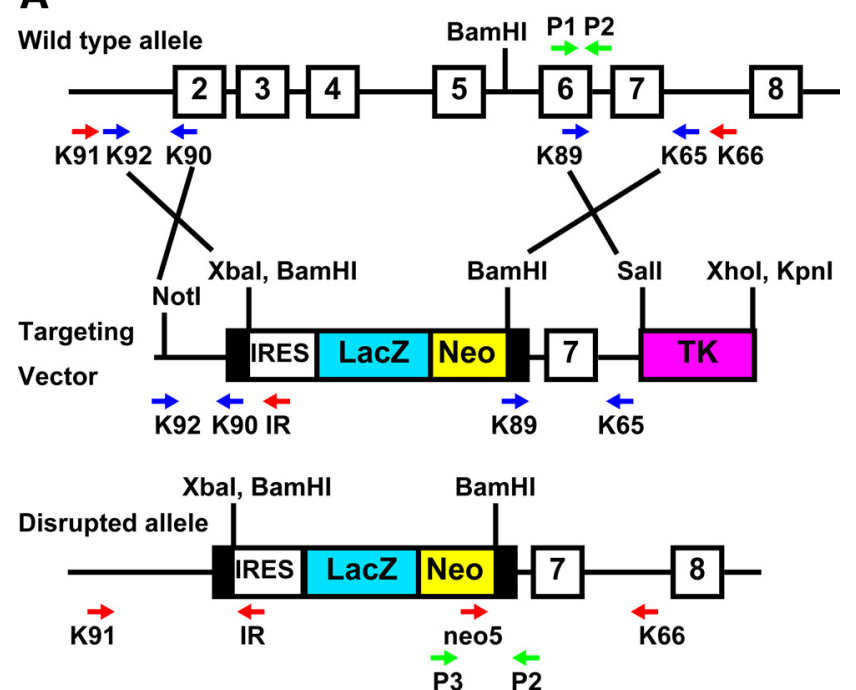

B
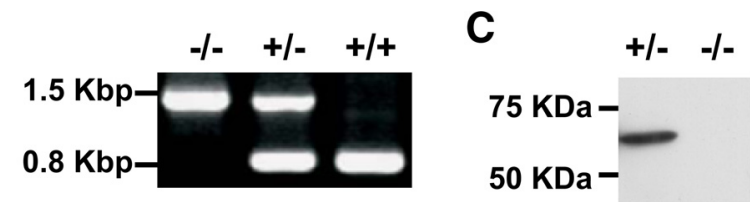

Figure 1. Targeted disruption of the crmp 5 gene. $\boldsymbol{A}$, Structure of the wild type gene, targeting vector, and disrupted locus. Positions of oligonucleotide primers used for screening and confirmation of homologous recombination are indicated. $\boldsymbol{B}$, Gene types of $\mathrm{crmp} 5^{-1-}$ (left), $\mathrm{Crmp5}^{+/-}$(middle), and $\mathrm{Crmp5}^{+/+}$(right). The $857 \mathrm{bp}$ fragment indicates wild type allele (primers P1 and P2), whereas the 1529 bp fragment indicates crmp5-deficient allele (primers P3 and P2). C, Immunoblot analysis of anti-CRMP5 antibody in $\mathrm{Crmp5}^{+/-}$and $\mathrm{Crmp5} 5^{-1-}$ mouse brain lysates. The final protein amount is $40 \mu \mathrm{g}$ each.

synaptic transmission between parallel fibers and Purkinje cells was deficient in $c r m p 5^{-/-}$mice. These findings suggest that CRMP5 plays a pivotal role in dendritic development and the function of Purkinje cell in the cerebellum.

\section{Materials and Methods}

Materials. Poly-L-lysine and L-glutamine were purchased from Sigma. Neurobasal medium, B27 and brain-derived neurotrophic factor (BDNF) were from Invitrogen. Monoclonal antibody against CRMP5 (KZ19) was raised by injecting full-length CRMP5 protein into $129 \mathrm{SvE}$ mouse. No signal was detected in $c r m p 5^{-1-}$ brain lysate (Fig. 1C). Other antibodies used were as follows: anti-calbindin (D28k; mouse monoclonal, Sigma), anti-microtubule associated protein $2 \mathrm{a}+2 \mathrm{~b}$ (MAP2) (mouse monoclonal, Sigma), anti-p-Tyr (PY99; mouse monoclonal, Santa Cruz Biotechnology), anti-V5 (mouse monoclonal, Invitrogen), Alexa Fluor 488- or 594-labeled goat anti-mouse (Invitrogen), and horseradish peroxidase-labeled sheep anti-mouse (GE Healthcare).

Construction of targeting vector and screening for targeted embryonic stem cell clones. The CRMP5 genomic fragments were isolated from R1 ES (embryonic stem) cell DNA by PCR amplification. CRMP5-specific primers with restriction sites overhangs, derived from the CRMP5 genomic sequence, were used to amplify second and sixth + seventh introns with adjacent exon sequences (Fig. 1A): K92: CCGCGGCCGCCAGATGTGCACAGTGATGTATTGTG, first intron, forward, NotI site; K90: GCGTCTAGACTTCTCATAGGCTTCCACGAG, second exon, reverse, Xba1 site; K89: GCGGGATCCTGGTCAATGTGTCTAGTATCTCA, sixth exon, forward, BamH1 site; K65: CGCGTCGACTGATGTTTTCCAGTCGGTATTCTG; seventh intron, reverse, Sall site.

The primer pair K90 and K92 amplified 5 kb fragment corresponding the first intron and a part of the second exon. The pair K89 and K65 amplified a $3 \mathrm{~Kb}$ segment representing part of the sixth exon, sixth intron, seventh exon, and part of the seventh intron. Sequencing of the
PCR products confirmed their identity and revealed the predicted exon/ intron boundaries. The $5 \mathrm{~Kb}$ and $3 \mathrm{~Kb}, 5^{\prime}$ and $3^{\prime}$ CRMP5 fragments, were then inserted into the PIRES - LacZ - neo cassette position such that it would disrupt and delete three exons of CRMP5 gene (exons 3, 4, 5). HSV TK gene was added to the $3^{\prime}$ end of the construct as a negative selection marker. NotI linearized vector $(25 \mu \mathrm{g})$ was electroporated $(240 \mathrm{~V}, 500 \mu \mathrm{F})$ into $2 \times$ $10^{7} \mathrm{R} 1 \mathrm{ES}$ cells (Nagy et al., 1993). The electroporated ES cells were selected with $150 \mu \mathrm{g} / \mathrm{ml} \mathrm{G} 418$ (active form) and 2 nM GANC. DNA of individual ES colonies was screened by PCR with a forward neo primer (primer neo5: TATCGCCTTCTTGACGAGTTCTTCTGA) and a primer from the seventh intron outside of the homologous region used in the vector (primer K66: CGCGTCGACATGCTTAACCGAAGGAATTATACCAGAATG). PCR conditions consisted of 36 cycles of $94^{\circ} \mathrm{C}$ for $20 \mathrm{~s}, 63^{\circ} \mathrm{C}$ for $40 \mathrm{~s}$, and $72^{\circ} \mathrm{C}$ for 4 min using BRL Taq polymerase. The recombination was confirmed on the 5 ' end using a forward primer from the first intron outside of the homologous region used in the construct (primer K91: CCGCGGCCGCTTTGCCCATGTGCCTTCTTGACA) and a reverse primer from the internal ribosomal entry site (IRES) sequence (primer IR: GGGCGGAATTCTCTAGCTAGA). Five positive colonies were identified from $\sim 200$ colonies screened.

Generation of crmp5 mutant mice. Targeted ES cells were injected into C57BL/6 blastocysts and implanted into pseudopregnant females. Male chimeras were mated initially with C57BL/6 females to screen for germline transmission. A transmitting chimeric male was then bred with 129 SvE females. Homozygous mutant mice were obtained by intercrossing the heterozygotes and screening the progeny by PCR genotyping (Fig. $1 B$ ). The wild type allele was amplified by forward primer P1 (CAAGCCTGGCTTTTCTCCTGGGTATGT) derived from the portion of the sixth exon deleted in the targeted allele and reverse primer P2 (CACATGCCCACTGGAACCAGTTTAGCA) derived from the portion of the sixth intron. The $c r m p 5$-deficient allele was amplified by forward primer P3 (TACCGTAAAGCACGAGGAAGCGGTCA) derived from the portion of neo gene and reverse primer P2 (Fig. $1 A$ ). Mice were housed in the standard mouse facility and fed with autoclaved diet and water. All procedures were performed according to the guideline outlined in the institutional Animal Care and Use Committee of the Yokohama City University School of Medicine. Throughout the experimental procedures, all efforts were made to minimize the number of animals used and their suffering. For electrophysiology, we used male mice. For the rest of the experiments including immunohistochemistry and cell culture, we did not determine the gender of the mice used.

Immunohistochemistry. Cryostat brain sections (10 $\mu \mathrm{m}$ thick) were treated with $0.1 \%$ Triton X-100 in TBST for $10 \mathrm{~min}$ at room temperature. Immunostaining was performed according to standard protocols using anti-calbindin (1:500) and anti-CRMP5 (1:200) antibodies. Slides were analyzed using a laser scanning microscope (LSM510) with a $20 \times$ objective (Plan-NEO FLUAR 20x/50) equipped with an Axioplan 2 imaging microscope (Carl Zeiss). To compare the Purkinje cell morphology, the long axis of soma and the width of primary dendrite were measured by using LSM 5 Image software (Carl Zeiss).

Electrophysiology. Mice were anesthetized with ether and decapitated. The cerebellum was excised and placed in ice-cold artificial CSF (ACSF) containing the following (in mM): $125 \mathrm{NaCl}, 2.5 \mathrm{KCl}, 1.25 \mathrm{NaH}_{2} \mathrm{PO}_{4}, 26$ $\mathrm{NaHCO}_{3}, 1 \mathrm{MgSO}_{4}, 2 \mathrm{CaCl}_{2}$, and $20 \mathrm{D}$-glucose, saturated with $95 \%$ $\mathrm{O}_{2} / 5 \% \mathrm{CO}_{2}$. Sagittal slices $(300 \mu \mathrm{m})$ were prepared from the cerebellar vermis. A whole-cell patch-clamp recordings of Purkinje cells were obtained with glass pipettes (resistance 3-4 M $\Omega$ ) filled with an intrapipette solution containing the following (in $\mathrm{mm}$ ): $40 \mathrm{Cs}$-gluconate, $60 \mathrm{CsCl}, 30$ HEPES, 0.3 EGTA, $4 \mathrm{MgCl}_{2}$, $4 \mathrm{Na}_{2}$ ATP, $0.4 \mathrm{Na}_{3} \mathrm{GTP}$ (pH 7.2 adjusted by $\mathrm{CsOH})$. Membrane current was recorded in picrotoxin (100 $\mu \mathrm{M})$ containing ACSF at $30^{\circ} \mathrm{C}$ with a Multiclamp700A amplifier using pClamp 9 software (Molecular Devices). Parallel fibers (PFs) were focally stimulated in the middle molecular layer through glass pipettes.

Primary culture. Hippocampal neurons from E16.5 brains of crmp $5^{+1-}$ or $\operatorname{crmp} 5^{-1-}$ mice were plated on 4 -well dishes (Nalgene) coated with poly-L-lysine at a density of $5 \times 10^{4}$ cells/well and grown in Neurobasal medium supplemented with $2 \% \quad$ B27 and 0.5 mm L-glutamine. Cultured neurons were fixed for immunocytochemistry to estimate the effects of BDNF on primary dendrite formation. BDNF (50 

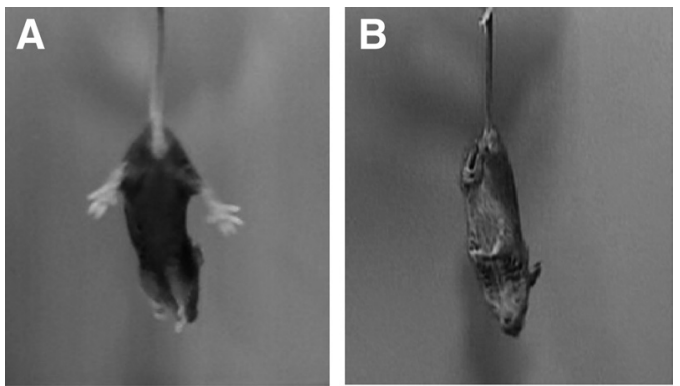

Figure 2. Abnormal limb-clasping reflex in $\mathrm{Crmp5}^{-/-}$mice. $\boldsymbol{A}, \boldsymbol{B}$, Limb-clasping reflex test was performed at $\mathrm{P} 28$ in $\mathrm{Crmp5}^{+/-}(\boldsymbol{A})$ and $\mathrm{Crmp5}^{-1-}(\boldsymbol{B})$ mice. Abnormal limb-clasping reflex was observed in eight of $28 \mathrm{crmp5}^{-1-}$ mice.
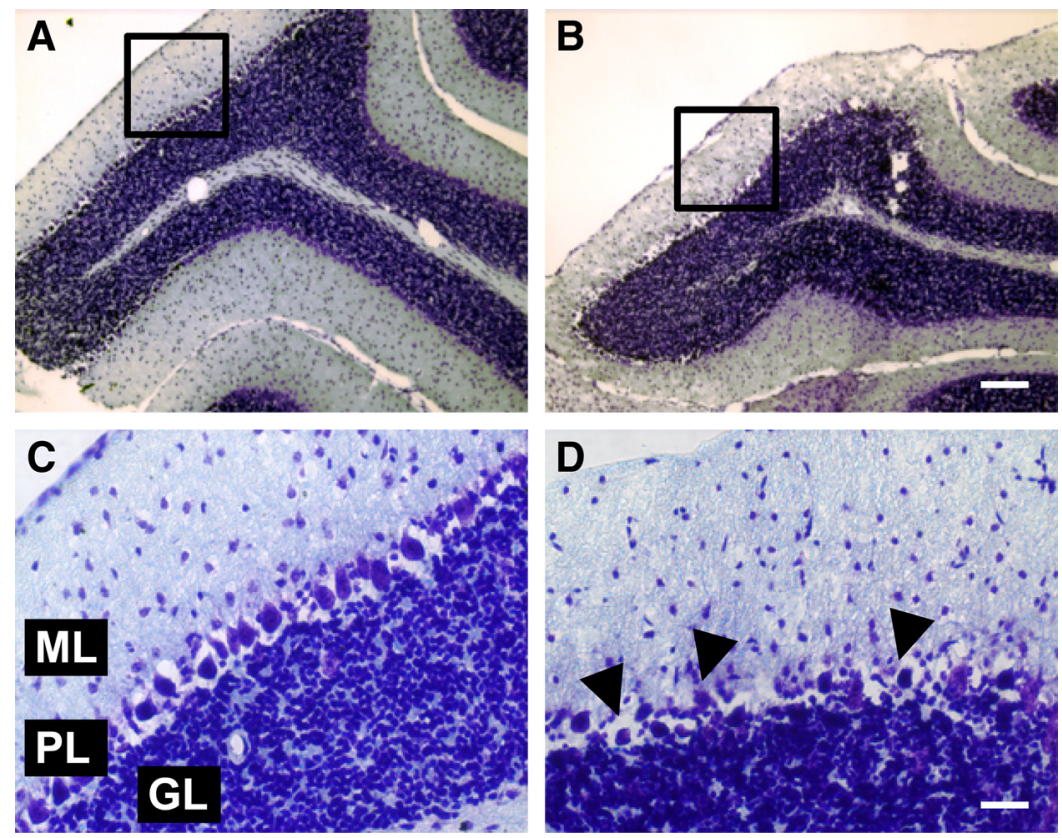

Figure 3. Aberrant morphology of Purkinje cells in $\mathrm{rrmp}^{-1-}$ mouse cerebellum. $A-D$, Nissl staining of the cerebellar cortex at P21 of $\mathrm{crmp5}^{+/-}(\boldsymbol{A}, \boldsymbol{C})$ and $\mathrm{crmp5} 5^{-1-}(\boldsymbol{B}, \boldsymbol{D})$. Magnified images of boxed area in $\boldsymbol{A}$ and $\boldsymbol{B}$ are shown in $\boldsymbol{C}$ and $\boldsymbol{D}$, respectively. Arrowhead shows the atrophy of Purkinje cells. Scale bars: (in B), $200 \mu \mathrm{m}$; (in D), $100 \mu \mathrm{m}$. ML, Molecular layer; PL, Purkinje cell layer; GL, granule cell layer.

$\mathrm{ng} / \mathrm{ml}$ ) was applied at $3 \mathrm{~d}$ in vitro and then cultured for further $3 \mathrm{~d}$ before fixation.

Immunocytochemistry. Cultured neurons were fixed in 2\% paraformaldehyde for $20 \mathrm{~min}$ at room temperature followed by permeabilization $0.1 \%$ Triton X-100 in PBS. Immunostaining was performed using anti-MAP2 antibody (1:1000) for counting the number of primary dendrites per cell in each experimental group. Cells were analyzed using Olympus IX-71 microscopy using a $10 \times$ objective.

In vivo phosphorylation assay. HEK293T cells were seeded at $2.0 \times 10^{5}$ cells/well in a six-well plate (Nalgene). One day later, the cells were transfected with CRMP5-V5 with or without the neurotrophic tyrosine kinase receptor type 2 (TrkB) expression vector using Fugene6 transfection reagent (Roche). After $24 \mathrm{~h}$, cells were lysed by immunoprecipitation buffer [in mu: 20 Tris- $\mathrm{HCl}, \mathrm{pH}$ 8.0, $150 \mathrm{NaCl}, 1$ EDTA, $10 \mathrm{NaF}, 1$ $\mathrm{Na}_{3} \mathrm{VO}_{4}, 1 \%$ Nonidet P-40, 50 -amidinophenylmethanesulfonyl fluoride ( $p$-APMSF), and $10 \mu \mathrm{g} / \mathrm{ml}$ aprotinin] and then immunoprecipitated with $1 \mu \mathrm{g}$ of anti-V5 antibody. The samples were used for immunoblot analysis of anti-V5 (1:5000) and anti-p-Tyr (1:5000) antibodies.

Statistical significance. Data are shown as mean \pm SEM. The statistical significance of the results was analyzed using Student's $t$ test and one-way ANOVA.

\section{Results}

Behavioral disorders in $\mathrm{crmp} 5^{-/-}$mice

To investigate the in vivo function of CRMP5, crmp $5^{-1-}$ mice were generated by homologous recombination using mouse $\mathrm{R} 1$ ES cells (Fig. 1A). The crmp $5^{+/-}$mice were normal compared with its wild-type littermates (data not shown). In addition, the crmp $5^{-1-}$ mice appeared normal, without any obvious gross abnormalities, they reproduced normally, and their average life span was almost the same as $c r m p 5^{+/-}$and wild-type animals (data not shown). In rotating rod test, no particular impairment of motor coordination was observed in $c r m p 5^{-1-}$ mice (data not shown). However, adult crmp $5^{-l-}$ mice showed abnormal limb-clasping reflexes when lifted by the tail. While the adult crmp $5^{-1-}$ mice clasped their hind limbs, the $\mathrm{crmp5}^{+/-}$mice extended their hind limbs (Fig. 2). This behavioral disorder may suggest the impairment of the CNS (Liou et al., 2003; Chen et al., 2005; Komatsu et al., 2006).

\section{Aberrant Purkinje cell morphology in the $\operatorname{crmp5} 5^{-1-}$ cerebellum \\ Our histological examination using brain sections stained with cresyl violet revealed that the gross cytoarchitecture was nor- mal (data not shown). However, the size of the Purkinje cell body in crmp $5^{-1-}$ mice tends to be smaller than that of crmp $5^{+/-}$mice at postnatal day 21 (P21) (Fig. 3). To further investigate this aberrant Purkinje cell morphology, we performed immunohistochemistry with anti-calbindin antibody and measured the long axis of the Purkinje cell soma and the width of its primary dendrite. At P21 and P28, the size of the Purkinje cell body was smaller and the diameter of its primary dendrite was thinner in $c r m p 5^{-l-}$ mice (Fig. 4). Interestingly, these abnormal phenotypes were not observed in P14 crmp5 $5^{-1-}$ mice (Fig. 4). These results suggest that the impairment in the Pur- kinje cells develop after P14.}

\section{CRMP5 expression is detected in the cerebellar Purkinje cells at P21 and P28, but not P14}

To elucidate the reason the aberrant morphology of the Purkinje cell is observed at P21 and P28 but not at P14, we examined CRMP5 expression profile in the cerebellum with anti-CRMP5 monoclonal antibody. In the cerebellar Purkinje cells, CRMP5 expression is observed in adult mice (Ricard et al., 2001; Bretin et al., 2005). At P14, the cells surrounding the Purkinje cells were positively stained with anti-CRMP5 antibody, while signal was absent in the Purkinje cell in $c r m p 5^{+/-}$mice (Fig. 5A). Interestingly, the Purkinje cells were clearly stained with anti-CRMP5 antibody at P21 and P28 in $\mathrm{crmp}^{+/-}$cerebellum (Fig. $5 B, C$ ). No signal was observed in the $c r m p 5^{-1-}$ cerebellum (Fig. $5 D-F$ ), indicating that the immunoreactive signal of anti-CRMP5 antibody is specific to CRMP5. These results suggest that the absence of CRMP5 may disturb the development of the Purkinje cells postnatally, especially during dendritic development (McKay and Turner, 2005). 
Long-term depression of parallel fibers and Purkinje cells in crmp5 $5^{-1-}$ mice Since deficits in motor learning is associated with physiological deficits of synaptic plasticity (Ito, 1986; Aiba et al., 1994), we investigated whether it is possible to induce LTD of excitatory synaptic transmission between PFs and Purkinje cells in crmp5 $5^{-1-}$ mice. LTD was induced by conjunctively applying PF stimuli and depolarizing pulses (single pulses, $100 \mathrm{~ms}$ duration; from -70 to $+10 \mathrm{mV}$ ) at $1 \mathrm{~Hz}$ for $5 \mathrm{~min}$ after reaching stable recordings of EPSCs during PF stimulation at $0.05 \mathrm{~Hz}$ for 10 min (Koekkoek et al., 2005). Conjunctive stimulation induced significant LTD of PF-EPSCs in Purkinje cell of crmp5 $5^{+/-}(99.9 \pm 0.4 \%$ during -4 to 0 $\min ; 72.7 \pm 3.3 \%$ during $26-30 \mathrm{~min} ; n=$ $5, p<0.01)$, but did not induce LTD in crmp5 $5^{-1-}(99.2 \pm 0.7 \%$ during -4 to 0 $\min , 92.7 \pm 4.2 \%$ during $26-30 \mathrm{~min} ; n=$ $6, p>0.1, n=5$ ) (Fig. 6). The amplitude of EPSCs measured during 26-30 min after conjunctive stimulation was significantly smaller in $c r m p 5^{+/-}$than that in crmp5 $5^{-1-}\left(72.7 \pm 3.3 \%\right.$ in $c r m p 5^{+/-}$, $92.7 \pm 4.2 \%$ in $\left.c r m p 5^{-/-}, p<0.05\right)$. Kinetic properties of PF-PC (Purkinje cell) EPSCs were examined between $c r m p 5^{+/-}$ and $c r m p 5^{-1-}$, but no significant difference was detected in rising time (10-90\%) (1.2 \pm $0.1 \mathrm{~ms}$ in $\mathrm{crmp5}^{+/-}, 1.2 \pm 0.1 \mathrm{~ms}$ in crmp $5^{-/-)}$nor decay time constant (11.6 \pm $1.8 \mathrm{~ms}$ in $\mathrm{crmp}^{+/-}, 11.7 \pm 2.3 \mathrm{~ms}$ in crmp5 $^{-1-)}$.

Attenuated response to BDNF in cultured crmp5 $^{-1-}$ neurons

In addition to being involved in Sema3A signaling (Goshima et al., 1995; Uchida et al., 2005), CRMPs are also implicated in the neurite extension, which is controlled by a wide range of neurotrophins (Quach et al., 2004; Yoshimura et al., 2005). One of the neurotrophins, BDNF, has been known to play a role in regulating dendritic arborization and synaptic neurotransmission (Gao et al., 1995; Schwartz et al., 1997; Carter et al., 2002; Horch and Katz, 2002). We therefore examined the possibility that CRMP5 is involved in neurotrophin signaling. Since CRMP5 is expressed in Purkinje cells only after P14 (Bretin et al., 2005; Hotta et al., 2005) (Fig. 5), it is difficult to examine the effect of BDNF at such elaborate dendritic stage using culture system. In contrast, CRMP5 is expressed in the early stages of hippocampal development (Hotta et al., 2005). We therefore used hippocampal neurons taken from early embryonic stage (E16.5) for primary culture neurons and examined the effect of BDNF regarding to primary dendrite formation (Cheung et al., 2007). BDNF, when added to the culture medium, increased the number of primary dendrites per hippocampal neuron obtained from crmp $5^{+/-}$mice. In contrast, this effect of BDNF was not observed in cultured hippocampal neurons from $c r m p 5^{-1-}$ mice (Fig. 7A-
E), indicating that CRMP5 was involved in mediating BDNF signaling. In addition, immunohistochemistry with anti-MAP2 antibody showed the MAP2 protein level was decreased in the hippocampus of $\mathrm{crmp} 5^{-1-}$ mouse at P21 when compared with it of $c r m p 5^{+/-}$mouse (Fig. $7 F, G$ ).

\section{CRMP5 is phosphorylated by TrkB in HEK293T cells}

A wide variety of biological effects of BDNF are mediated through TrkB receptor tyrosine kinase, a receptor for BDNF. To further clarify the role of CRMP5 in BDNF signaling, we examined whether CRMP5 was phosphorylated by TrkB. In HEK 293T cells, CRMP5 was tyrosine phosphorylated in the presence of TrkB (Fig. 7H). This result showed that CRMP5 was phosphorylated by $\operatorname{TrkB}$. 

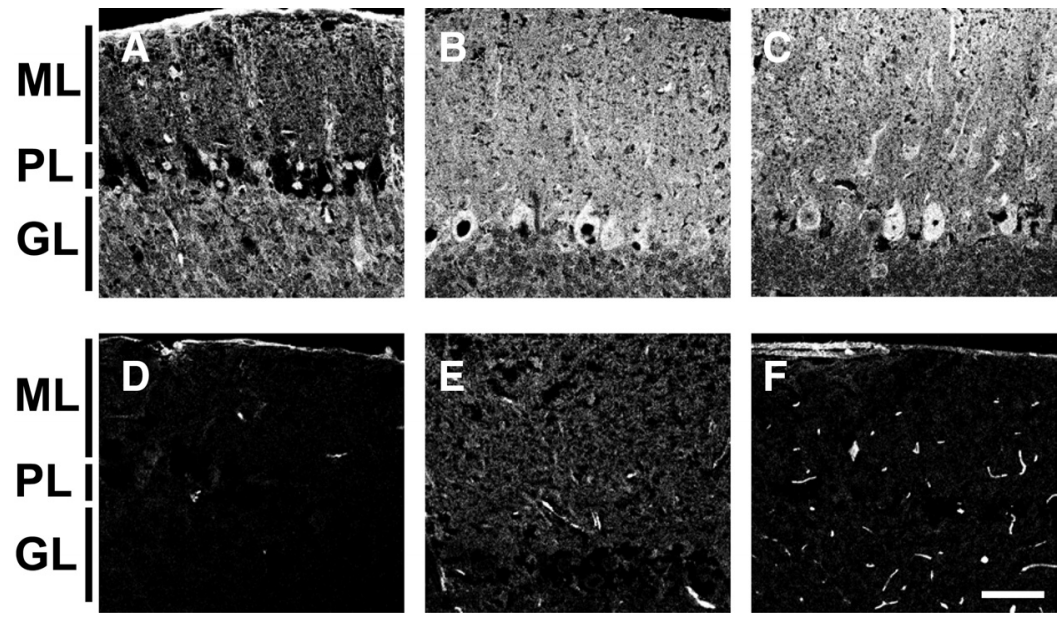

Figure 5. Expression of CRMP5 in the cerebellar cortex. $\boldsymbol{A}-\boldsymbol{F}$, The sagittal sections of $\mathrm{crmp} 5^{+/-}(\boldsymbol{A}-\boldsymbol{C})$ and $\mathrm{crmp} 5^{-1-}(\boldsymbol{D}-\boldsymbol{F})$ mice at P14 $(\boldsymbol{A}, \boldsymbol{D}), \mathrm{P} 21(\boldsymbol{B}, \boldsymbol{E})$ and P28 $(\boldsymbol{C}, \boldsymbol{F})$ were immunostained with anti-CRMP5 antibody. CRMP5 was expressed in ML and GL at P14 (A). In addition to ML and GL, CRMP5 was also expressed in PL at P21 and P28 (B, C). No CRMP5 signals were detected in $\mathrm{Crmp5}^{-1-}$ mouse brain $(\boldsymbol{D}-\boldsymbol{F})$. Scale bar, $50 \mu \mathrm{m}$.

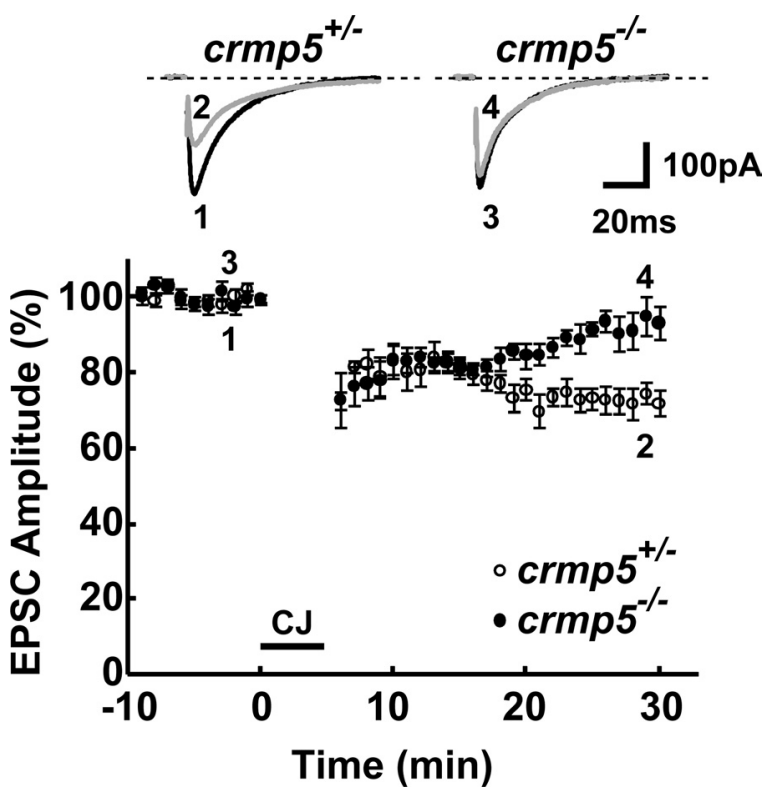

Figure 6. Failure of LTD of PF-PC EPSCs in $c r m p 5^{-1-}$ mice. LTD of PF-PC EPSCs is deficient in $\mathrm{Crmp5}^{-1-}$. Conjunctive stimulation (C) induced LTD in $\mathrm{Crmp5}^{+/-}$, but not in $\mathrm{Crmp5}^{-/-}$. Insets show sample traces of PF-EPSCs taken at time points 1 (black) and 2 (gray) in $\mathrm{Crmp}^{+/-}$ or at 3 (black) and 4 (gray) in $\mathrm{crmp}^{-1-}$.

\section{Discussion}

In the present study, we first demonstrate that CRMP5 is required for the proper development of the Purkinje cells in the cerebellum, especially during Purkinje cell dendritic branching period. In P14 crmp5 $5^{-1-}$ mice, dendritic arborization and cell morphology of the Purkinje cells appeared to be normal, compared with those in $\mathrm{crmp}^{+/-}$mice. However, in P21 and P28 crmp5 $5^{-/-}$ mice, the soma and dendritic diameter of Purkinje cells were aberrant (Fig. 4). The morphology changes observed in Purkinje cells may be related to the expression profile of CRMP5 in developing cerebellum: CRMP5 was observed at P21 and P28 but not at P14 of the Purkinje cells (Fig. 5). The coincidental transient CRMP5 expression profile and the phenotypic defect in $c r m p 5^{-1-}$ mice at the later postnatal stages support the idea that expression of
CRMP5 during a certain period of time is required for the proper dendritic development of Purkinje cells.

We found that the effect of BDNF was impaired in the cultured hippocampal neurons from $c r m p 5^{-1-}$ brains (Fig. $7 A-$ $E)$. In addition, CRMP5 was tyrosine phosphorylated by TrkB (Fig. 7H). These findings together suggest that CRMP5 may be involved in BDNF signaling and together they regulate dendritic morphology of the Purkinje cells. The period of morphological changes observed in crmp $5^{-/-}$Purkinje cell is well correlated with the CRMP5 expression profile at the cerebellar Purkinje cells, though granular cells expressed CRMP5 even at P14 (Figs. $4,5)$. This fact suggests that CRMP5 regulates dendritic morphology of the Purkinje cells through cell autonomous effect of BDNF-TrkB signaling. The expression profile of CRMP5 further suggests that CRMP5 becomes involved in BDNF-TrkB signaling after P14 (Fig. 5). In the postnatal stage, BDNF-TrkB signaling regulates dendritic spine density but not dendritic outgrowth (Shimada et al., 1998). Other CRMP family members, CRMP1 and CRMP3, have shown to positively regulate dendritic spine density (Yamashita et al., 2006; Quach et al., 2008). Hence, the loss of CRMP5 may impair BDNF-regulated dendritic spine density and thereby caused impairment of LTD (Fig. 6). Since the formation of LTD is required for the activity of AMPA-type and metabotropic glutamate receptors (Raymond et al., 1993), the suppression of the activity of these receptors can lead to a decrease in the diameter of Purkinje cell dendrite (Hirai and Launey, 2000). The atrophied phenotype seen in the $c r m p 5^{-1-}$ Purkinje cell dendrites may be therefore explained by the secondary effects of impairment of LTD in the crmp $5^{-1-}$ cerebellum. In addition to the possible involvement of CRMP5 in BDNF-TrkB signaling, CRMP5, may also be a possible modifier of tubulin (Brot et al., 2010), which may explain the abnormalities in dendritic development and impairment of LTD. The behavioral disorders such as abnormal limb clasping reflexes observed in crmp $5^{-1-}$ mice may be caused by some failure of network formation and/or synaptic plasticity in the CNS.

CRMP family proteins are consisted of CRMP1-5 and their splicing variants, each shows distinct distribution patterns in the peripheral and CNS (Wang and Strittmatter, 1996; Fukada et al., 2000). Yeast two hybrid and in vitro binding analysis suggest that the interactions among isoforms favor heterophilic oligomerization over homophilic oligomerization (Wang and Strittmatter, 1997). CRMP5 interacts with CRMP2, CRMP3 and CRMP4, but not with CRMP1 (Fukada et al., 2000). During size exclusion chromatography, purified bovine CRMP migrates as a tetramer (Wang and Strittmatter, 1997), suggesting that CRMP family proteins may play their distinct roles by forming hetero-oligomeric complexes in vivo. To address this issue, future studies will be required to determine whether there are genetic interactions among these crmp gene-deficient mutant mice. In conclusion, CRMP5 plays an important role in dendritic development of Purkinje cells in the cerebellum. CRMP5 probably regulates dendritic development by mediating BDNF signaling in the CNS. 


\section{References}

Aiba A, Kano M, Chen C, Stanton ME, Fox GD, Herrup K, Zwingman TA, Tonegawa S (1994) Deficient cerebellar long-term depression and impaired motor learning in mGluR1 mutant mice. Cell 79:377-388.

Bretin S, Reibel S, Charrier E, Maus-Moatti M, Auvergnon N, Thevenoux A, Glowinski J, Rogemond V, Prémont J, Honnorat J, Gauchy C (2005) Differential expression of CRMP1, CRMP2A, CRMP2B, and CRMP5 in axons or dendrites of distinct neurons in the mouse brain. J Comp Neurol 486:1-17.

Brot S, Rogemond V, Perrot V, Chounlamountri N, Auger C, Honnorat J, Moradi-Améli M (2010) CRMP5 interacts with tubulin to inhibit neurite outgrowth, thereby modulating the function of CRMP2. J Neurosci 30:10639-10654.

Byk T, Dobransky T, Cifuentes-Diaz C, Sobel A (1996) Identification and molecular characterization of Unc-33-like phosphoprotein (Ulip), a putative mammalian homolog of the axonal guidance-associated unc-33 gene product. J Neurosci 16:688-701.

Carter AR, Chen C, Schwartz PM, Segal RA (2002) Brain-derived neurotrophic factor modulates cerebellar plasticity and synaptic ultrastructure. J Neurosci 22:1316-1327.

Charrier E, Mosinger B, Meissirel C, Aguera M, Rogemond V, Reibel S, Salin P, Chounlamountri N, Perrot V, Belin MF, Goshima Y, Honnorat J, Thomasset N, Kolattukudy P (2006) Transient alterations in granule cell proliferation, apoptosis and migration in postnatal developing cerebellum of CRMP1-/- mice. Genes Cells 11:1337-1352.

Chen YT, Collins LL, Uno H, Chang C (2005) Deficits in motor coordination with aberrant cerebellar development in mice lacking testicular orphan nuclear receptor 4. Mol Cell Biol 25:2722-2732.

Cheung ZH, Chin WH, Chen Y, Ng YP, Ip NY (2007) Cdk5 is involved in BDNF-stimulated dendritic growth in hippocampal neurons. PLoS Biol 5:e63.

Cross SA, Salomao DR, Parisi JE, Kryzer TJ, Bradley EA, Mines JA, Lam BL, Lennon VA (2003) Paraneoplastic autoimmune optic neuritis with retinitis defined by CRMP-5-IgG. Ann Neurol 54:38-50.

Fukada M, Watakabe I, Yuasa-Kawada J, Kawachi H, Kuroiwa A, Matsuda Y, Noda M (2000) Molecular characterization of CRMP5, a novel member of the collapsin response mediator protein family. J Biol Chem 275:37957-37965

Fukata Y, Itoh TJ, Kimura T, Ménager C, Nishimura T, Shiromizu T, Watanabe H, Inagaki N, Iwamatsu A, Hotani H, Kaibuchi K (2002) CRMP-2 binds to tubulin heterodimers to promote microtubule assembly. Nat Cell Biol 4:583-591.

Gao WQ, Zheng JL, Karihaloo M (1995) Neurotrophin-4/5 (NT-4/5) and brain-derived neurotrophic factor (BDNF) act at later stages of cerebellar granule cell differentiation. J Neurosci 15:2656-2667.

Goshima Y, Nakamura F, Strittmatter P, Strittmatter SM (1995) Collapsininduced growth cone collapse mediated by an intracellular protein related to UNC-33. Nature 376:509-514.

Hamajima N, Matsuda K, Sakata S, Tamaki N, Sasaki M, Nonaka M (1996) A novel gene family defined by human dihydropyrimidinase and three related proteins with differential tissue distribution. Gene 180:157-163.

Hirai H, Launey T (2000) The regulatory connection between the activity of granule cell NMDA receptors and dendritic differentiation of cerebellar Purkinje cells. J Neurosci 20:5217-5224.

Honnorat J, Antoine JC (2007) Paraneoplastic neurological syndromes. Orphanet J Rare Dis 2:22.

Horch HW, Katz LC (2002) BDNF release from single cells elicits local dendritic growth in nearby neurons. Nat Neurosci 5:1177-1184.

Hotta A, Inatome R, Yuasa-Kawada J, Qin Q, Yamamura H, Yanagi S (2005)
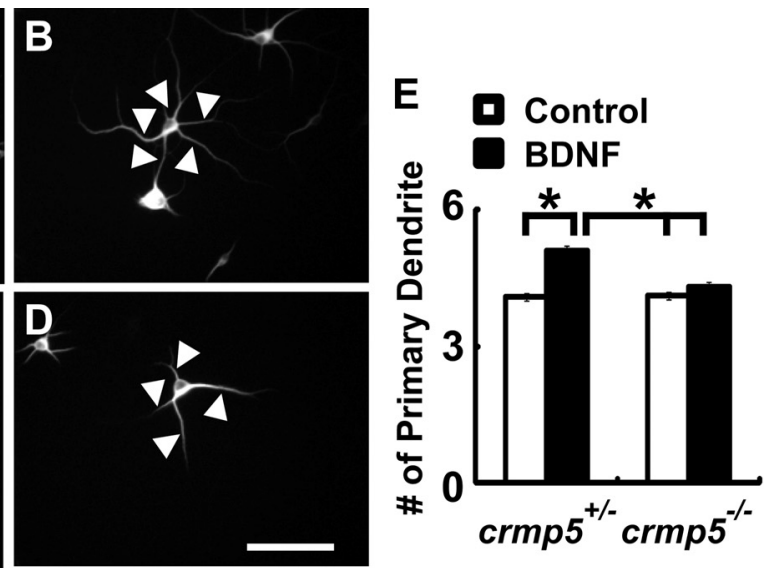

G

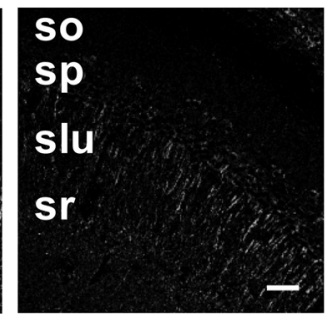

H

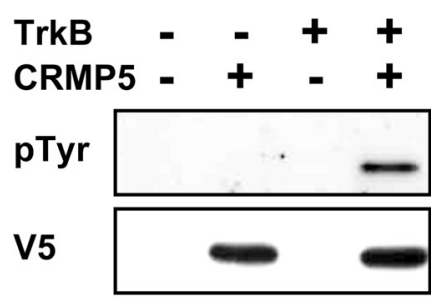

Figure 7. The effect of BDNF on primary dendrite formation in cultured hippocampal neurons. $A-D$, The hippocampal neurons dendrites. Scale bar, $100 \mu \mathrm{m}$. $\boldsymbol{E}$, Number of primary dendrites of cultured hippocampal neurons $(n=150$ from five . so, Stratum oriens; sp, stratum pyramidale; slu, stratum lucidum; sr, stratum radiatum. Scale bar, $100 \mu \mathrm{m} . \boldsymbol{H}$ ine phosphorylation of CRMP5 by TrkB. CRMP5-V5 was introduced with or without TrkB in HEK293T cells. Immunoprecipitation with anti-V5 antibody was performed and was thereafter immunoblotted with anti-p-Tyr and anti-V5 antibodies.

Critical role of collapsin response mediator protein-associated molecule CRAM for filopodia and growth cone development in neurons. Mol Biol Cell 16:32-39.

Inatome R, Tsujimura T, Hitomi T, Mitsui N, Hermann P, Kuroda S, Yamamura H, Yanagi S (2000) Identification of CRAM, a novel unc-33 gene family protein that associates with CRMP3 and protein-tyrosine kinase(s) in the developing rat brain. J Biol Chem 275:27291-27302.

Ito M (1986) Long-term depression as a memory process in the cerebellum. Neurosci Res 3:531-539.

Koekkoek SK, Yamaguchi K, Milojkovic BA, Dortland BR, Ruigrok TJ, Maex R, De Graaf W, Smit AE, VanderWerf F, Bakker CE, Willemsen R, Ikeda T, Kakizawa S, Onodera K, Nelson DL, Mientjes E, Joosten M, De Schutter E, Oostra BA, Ito M, De Zeeuw CI (2005) Deletion of FMR1 in Purkinje cells enhances parallel fiber LTD, enlarges spines, and attenuates cerebellar eyelid conditioning in Fragile X syndrome. Neuron 47:339-352.

Komatsu M, Waguri S, Chiba T, Murata S, Iwata J, Tanida I, Ueno T, Koike M, Uchiyama Y, Kominami E, Tanaka K (2006) Loss of autophagy in the central nervous system causes neurodegeneration in mice. Nature 441:880-884.

Liou YC, Sun A, Ryo A, Zhou XZ, Yu ZX, Huang HK, Uchida T, Bronson R, Bing G, Li X, Hunter T, Lu KP (2003) Role of the prolyl isomerase Pin 1 in protecting against age-dependent neurodegeneration. Nature 424:556-561.

Luo L (2000) Rho GTPases in neuronal morphogenesis. Nat Rev Neurosci 1:173-180.

McKay BE, Turner RW (2005) Physiological and morphological development of the rat cerebellar Purkinje cell. J Physiol 567:829-850.

Minturn JE, Fryer HJ, Geschwind DH, Hockfield S (1995) TOAD-64, a gene expressed early in neuronal differentiation in the rat, is related to unc-33, a C. elegans gene involved in axon outgrowth. J Neurosci 15:6757-6766.

Nagy A, Rossant J, Nagy R, Abramow-Newerly W, Roder JC (1993) Derivation of completely cell culture-derived mice from early-passage embryonic stem cells. Proc Natl Acad Sci U S A 90:8424-8428. 
Pittock SJ, Kryzer TJ, Lennon VA (2004) Paraneoplastic antibodies coexist and predict cancer, not neurological syndrome. Ann Neurol 56:715-719.

Quach TT, Duchemin AM, Rogemond V, Aguera M, Honnorat J, Belin MF, Kolattukudy PE (2004) Involvement of collapsin response mediator proteins in the neurite extension induced by neurotrophins in dorsal root ganglion neurons. Mol Cell Neurosci 25:433-443.

Quach TT, Massicotte G, Belin MF, Honnorat J, Glasper ER, Devries AC, Jakeman LB, Baudry M, Duchemin AM, Kolattukudy PE (2008) CRMP3 is required for hippocampal CA1 dendritic organization and plasticity. FASEB J 22:401-409.

Raymond LA, Blackstone CD, Huganir RL (1993) Phosphorylation of amino acid neurotransmitter receptors in synaptic plasticity. Trends Neurosci 16:147-153.

Ricard D, Rogemond V, Charrier E, Aguera M, Bagnard D, Belin MF, Thomasset N, Honnorat J (2001) Isolation and expression pattern of human Unc-33-like phosphoprotein 6/collapsin response mediator protein 5 (Ulip6/CRMP5): coexistence with Ulip2/CRMP2 in Sema3a-sensitive oligodendrocytes. J Neurosci 21:7203-7214.

Schwartz PM, Borghesani PR, Levy RL, Pomeroy SL, Segal RA (1997) Abnormal cerebellar development and foliation in BDNF- / - mice reveals a role for neurotrophins in CNS patterning. Neuron 19:269-281.

Shimada A, Mason CA, Morrison ME (1998) TrkB signaling modulates spine density and morphology independent of dendrite structure in cultured neonatal Purkinje cells. J Neurosci 18:8559-8570.

Su KY, Chien WL, Fu WM, Yu IS, Huang HP, Huang PH, Lin SR, Shih JY, Lin YL, Hsueh YP, Yang PC, Lin SW (2007) Mice deficient in collapsin response mediator protein-1 exhibit impaired long-term potentiation and impaired spatial learning and memory. J Neurosci 27:2513-2524.

Uchida Y, Ohshima T, Sasaki Y, Suzuki H, Yanai S, Yamashita N, Nakamura
F, Takei K, Ihara Y, Mikoshiba K, Kolattukudy P, Honnorat J, Goshima Y (2005) Semaphorin3A signalling is mediated via sequential Cdk5 and GSK3beta phosphorylation of CRMP2: implication of common phosphorylating mechanism underlying axon guidance and Alzheimer's disease. Genes Cells 10:165-179.

Wang LH, Strittmatter SM (1996) A family of rat CRMP genes is differentially expressed in the nervous system. J Neurosci 16:6197-6207.

Wang LH, Strittmatter SM (1997) Brain CRMP forms heterotetramers similar to liver dihydropyrimidinase. J Neurochem 69:2261-2269.

Yamashita N, Uchida Y, Ohshima T, Hirai S, Nakamura F, Taniguchi M, Mikoshiba K, Honnorat J, Kolattukudy P, Thomasset N, Takei K, Takahashi T, Goshima Y (2006) Collapsin response mediator protein $1 \mathrm{me}-$ diates reelin signaling in cortical neuronal migration. J Neurosci 26:13357-13362.

Yamashita N, Morita A, Uchida Y, Nakamura F, Usui H, Ohshima T, Taniguchi M, Honnorat J, Thomasset N, Takei K, Takahashi T, Kolattukudy P, GoshimaY (2007) Regulation of spine development by semaphorin3A through cyclin-dependent kinase 5 phosphorylation of collapsin response mediator protein 1. J Neurosci 27:12546-12554.

Yoshimura T, Kawano Y, Arimura N, Kawabata S, Kikuchi A, Kaibuchi K (2005) GSK-3beta regulates phosphorylation of CRMP-2 and neuronal polarity. Cell 120:137-149.

Yu Z, Kryzer TJ, Griesmann GE, Kim K, Benarroch EE, Lennon VA (2001) CRMP-5 neuronal autoantibody: marker of lung cancer and thymomarelated autoimmunity. Ann Neurol 49:146-154.

Yuasa-Kawada J, Suzuki R, Kano F, Ohkawara T, Murata M, Noda M (2003) Axonal morphogenesis controlled by antagonistic roles of two CRMP subtypes in microtubule organization. Eur J Neurosci 17:2329-2343. 